\title{
THE ORGANIZATION AND FUNCTIONING OF INDUSTRY COMMITTEES UNDER THE FAIR LABOR STANDARDS ACT
}

\author{
Z. Chark DrckinsoN*
}

The industry committees appointed by the Administrator under the Fair Labor Standards Act, giving equal representation to employers, workers, and the public with reference to each industry, are somewhat analogous to the wage or trade boards utilized by previous minimum wage legislation, in the American states and abroad. The former, however, are likely to become more numerous than the latter have been in any one state or nation; and it is not yet apparent whether they are destined to play as active and sustained a role in administration as have some minimum wage boards here and abroad. By the middle of June, I939 only seven industry committees had been appointed, most of them since January I, I939. Committee No. I, appointed in the early autumn of $193^{8}$, was designated the Textile Committee; the Apparel Committee (No. 2) was appointed later in 1938. Early in January, I939 (at the suggestion of members of Committee No. $x$ ) the textile field was divided, and Committee No. I-A was established to have jurisdiction over establishments using wool and other animal fibers, except silk. The other committees thus far appointed are No. 3, Hosiery, No. 4, Hats, No. 5, Millinery, and No. 6, Boots and Shoes. Each of these committees has been collecting evidence concerning its own industry for the purpose of assisting the Administrator in "reaching, as rapidly as is economically feasible without substantially curtailing employment, the objective of a universal minimum wage of 40 cents an hour...."

By early May three of the committees had agreed upon recommendations: cotton, $32 \frac{1}{2}$ cents; wool, $3^{6}$ cents; seamless hosiery, 321/2 cents; full-fashioned hosiery, 40 cents; but the division of jurisdiction as between the cotton and woolen industries remained to be cleared up. The Textile and Woolen industry committees met concurrently in Washington on May 22. They were unable to agree on consistent definitions of their respective industries; hence the Administrator was obliged to issue an order on such demarcation. He chose substantially the lines followed by the NRA codes, viz; fabrics of not more than 25 per cent wool content (by weight) to conform to the cotton textile minimum wage regulations, those over 25 per cent, to the woolen industry's minimum wage. Committee No. I thereupon completed its recommenda-

- A.B., IgI4, University of Nebraska; Ph. D., Ig20, Harvard University. Professor of Economics, University of Michigan. Member, Woolen Industry Committee, No. I-A. 
tion of a $32 \frac{1}{2}$ cent minimum wage for the textile industry with an opposing minority report; and Committee I-A renewed its recommendation of 36 cents. The Woolen Committee was disappointed that fabrics of lower than 25 per cent wool should not be subject to the woolen industry's minimum wage. The lower this breaking-point is made (with differing wage rates), the greater the protection of the woolen industry against the manufacture of blends of wool, cotton, and rayon, which have developed rapidly since NRA days.

By the first of June public hearings on recommendations had not yet begun. ${ }^{1}$ This deliberate pace, so sharply in contrast with NRA action, suggests more thorough and careful work; and, since the blanket minimum for all industries under the Act is advanced from 25 to 30 cents at the end of the first year, there has not been very urgent need for greater speed. In I940-45, however, while this blanket minimum remains at 30 cents, it is extremely important that many industry committees be activated to push up the minimum to 40 cents as gradually as may be needful.

The nature and work of these committees, so far as can be judged from a very limited contact with the limited experience thus far available, will be developed in this article by discussion of (i) the chief features concerning the committees, in the law and in the Administrator's regulations ${ }^{2}$ and practices, with reference to the scope and personnel of the committees; (ii) their functions, procedures, and problems; and (iii) some inferences as to their general significance in the administration of the Act. A few suggestions will be ventured as to how the committee scheme might be improved.

\section{Scope and Personnel of Committees}

The principal mandates in the Fair Labor Standards Act with specific reference to industry committees are contained in Sections 5, 8, and 9. Section 5 reads as follows:

Sec. 5. Industry Committees. (a) The Administrator shall as soon as practicable appoint an industry committee for each industry engaged in [interstate] commerce or in the production of goods for [such] commerce.

"(b) An industry committee shall be appointed by the Administrator without regard to any other provisions of law regarding the appointment and compensation of employees of the United States. It shall include a number of disinterested persons representing the public, one of whom the Administrator shall designate as chairman, a like number of persons representing employees in the industry, and a like number representing employers in the industry. In the appointment of the persons representing each group, the Administrator shall give due regard to the geographical regions in which the industry is carried on.

"(c) Two-thirds of the members of an industry committee shall constitute a quorum, and the decision of the committee shall require a vote of not less than a majority of all its

\footnotetext{
${ }^{1}$ Hearings on the recommendation of the Textile Committee were set for June ig in Washington and July 26 in Atlanta.

The Administrator's Regulations Applicable to Industry Committees, Purstuant to Section 5 of the Fair Labor Standards Act of 1938 (29 CoDE FED. REc. c. 5, Pt. 51 I, November, 1938) may be consulted with reference to any points in the following discussion of legal powers and rules of these committces which may not be clear by reference merely to the statute. See the issues of the Wage and Hour Reporter for many factual particulars, including releases from the Administrator's office.
} 
members. Members of an industry committee shall receive as compensation for their services a reasonable per diem, which the Administrator shall by rules and regulations prescribe, for each day actually spent in the work of the committee, and shall in addition be reimbursed for their necessary traveling and other expenses. The Administrator shall furnish the committee with adequate legal, stenographic, clerical, and other assistance, and shall by rules and regulations prescribe the procedure to be followed by the committee.

"(d) The Administrator shall submit to an industry committee from time to time such data as he may have available on the matters referred to it, and shall cause to be brought before it in connection with such matters any witnesses whom he deems material. An industry committee may summon other witnesses or call upon the Administrator to furnish additional information to aid it in its deliberations."

It will be observed that the Administrator is required to appoint such a committee for each "industry" of interstate significance, but no instruction is contained in the law as to how such industries may be defined. He also has full discretion as to the order in which the industry committees shall be appointed. It is much easier to define industries now than it would have been 20 years ago, of course, by reason of the growth of labor and trade organizations, particularly since inception of the NRA. The Administrator has appointed the industry committees named above, with the objective of dealing first with the larger bodies of low-paid workers; and it seems unlikely that demands will appear for anywhere near as many categories as were implied by the 500-odd codes of NRA. ${ }^{3}$

Numerous puzzles are encountered, however, in the search for demarcations between even the older and larger industries, for purposes of industry committee organization-particularly if the minimum wage rates are set differently for overlapping operations. Thus, as stated above, there was sufficient demand to lead the Administrator to set up Committee I-A for woolen and worsted textile establishments; and the duty was laid upon Committees I and I-A, through their subcommittees, to assist in determining to which establishments and/or departments their respective recommendations should apply. Many mills produce mixtures and blends of cotton, woolen, and other fibers, e.g., in blankets. Under NRA the higher minimum wage of the woolen code applied to all departments using 25 per cent or more of wool. In appointing each industry committee the Administrator commonly specifies a number of subindustries which are definitely included, but this demarcation usually has to be worked out further-for example, as to whether carpets and rugs made largely of wool should be covered by the woolen industry's minimum wage.

It will be noticed, by reference to subsection (b) of Section 5, quoted above, that each committee is to be composed of equal numbers of representatives of the public,

${ }^{3}$ Cf. Naming Indtustry Committees (1939) 2 WAGE \& Hour REP. I4I. According to this article, first to be named are committees for industries in which minimum hourly rates of from 30 to 40 cents (the blanket rate for all industries covered will be automatically raised to 30 cents in October 1939) will not substantially curtail employment, yet will correct material numbers of unduly low rates. Those industries in which few earnings, if any, are now below 40 cents, will doubtless be last to be provided with industry committecs. Among proposals under discussion in Congress, for amendment of this Act, is one for a separate industry committee to deal with very low wages in Puerto Rico and the Virgin Islands. 
the employees, and the employers; and that such representatives are to be appointed "with due regard to the geographical regions." Apart from these somewhat elastic directions the Administrator has full discretion. Naturally in choosing employer and labor members he attaches much weight to suggestions from the trade and labor organizations most directly concerned. Trade association executives have not been appointed as employer representatives; trade union executives have been so appointed. Choice of public representatives has been more puzzling. The Administrator has made a sincere and able effort to select these public members on the basis of merit, but merit for this rather novel function is an elusive factor. In some cases the public members are retail merchants, who are unusually conversant with technical details of the product and with the consumer's interest in its wage costs. Another main source of public members is the teaching profession.

Most of the committees thus far appointed are so large as to be rather unwieldy, and, in the aggregate, to become a bit of a drain on the funds available for the Act's administration. ${ }^{4}$ A chief reason for these numbers is the corresponding number of subdivisions within the industries, in each of which employers have desired representation. To some extent the total number of committeemen is kept down, and experience kept up, by overlapping appointments-identical persons representing the public and labor serving on two or more industry committees.

\section{Functions, Procedures, Problems}

From the foregoing review of conditions surrounding the appointment of an industry committee, we may pass to consideration of its functions, duties, and powers. The legislative mandates on these matters are found in Sections 8 and 9 of the Act. Section 9, pertaining to attendance of witnesses and summoning of books, papers, and documents, confers on the industry committees subpoena power in accordance with the Federal Trade Commission Act. ${ }^{5}$

Section 8, entitled "Wage Orders," is too lengthy to be quoted here as a unit, but several of its parts must be examined rather closely. Subsections (a) and (b) read as follows:

"(a) With a view to carrying out the policy of this Act by reaching, as rapidly as is economically feasible without substantially curtailing employment, the objective of a universal minimum wage of $4^{\circ}$ cents an hour in each industry engaged in [interstate] commerce or in the production of goods for [such] commerce, the Administrator shall from time to time convene the industry committee for each such industry, and the industry committee shall from time to time recommend the minimum rate or rates of wages to be paid under section $6 . .$.

"(b) Upon the convening of an industry committee, the Administrator shall refer to it the question of the minimum wage rate or rates to be fixed for such industry. The

\footnotetext{
t The numbers of persons on these committees are as follows: No. $x$, Textiles, 2x members; No. I-A, Wool and Worsted, I5 members; No. 2, Apparel, 48 members; No. 3, Hosiery, I5 members; No. 4, Hats, 15 members; No. 5, Millinery, 15 members; and No. 6, Boot and Shoe, 27 members. Members receive $\$ 15$ a day for service, beside subsistence and travel expense. All the full committec meetings have thus far been held in Washington; a few subcommittees have met elsewhere.

"See Herman, The Administration and Enforcement of the Fair Labor Standards Act, infra, p. 368. notes 99-ror.
} 
industry committee shall investigate conditions in the industry and the committee, or any authorized subcommittee thereof, may hear such witnesses and receive such evidence as may be necessary or appropriate to enable the committee to perform its duties and functions under this Act. The committee shall recommend to the Administrator the highest minimum wage rates for the industry which it determines, having due regard to economic and competitive conditions, will not substantially curtail employment in the industry."

These paragraphs indicate that the industry committee's function is limited to investigation and recommendation to the Administrator of what the committee, after due deliberation, considers the highest minimum wage rate (not over 40 cents per hour) which its industry can then stand. ${ }^{6}$ The limits, therefore, within which such recommendations fall are the blanket minimum provided for all industries by Section 6 and the highest minimum wage which may be applied as the Act now stands, i.e., 40 cents per hour.

No other duties or powers are explicitly provided by statute for any industry committee. The Administrator's regulations state that "An industry committee may, at any time, recommend to the Administrator that the scope of the industry as defined in the order appointing the committee be enlarged, modified, or restricted." (Section 5rr.I7). As indicated above, following suggestions from the Administrator, the existing committees and their subcommittees have given considerable study to this vital matter of interlocking industry-definition.

Subsection (c) of Section 8 authorizes any industry committee to recommend

"such reasonable classifications within any industry as it determines to be necessary for the purpose of fixing for each classification within such industry the highest minimum wage rate (not in excess of 40 cents an hour) which (I) will not substantially curtail employment in such classification and (2) will not give a competitive advantage to any group in the industry, and shall recommend for each classification in the industry the highest minimum wage rate which the committee determines will not substantially curtail employment in such classification. In determining whether such classifications should be made in any industry, in making such classifications, and in determining the minimum wage rates for such classifications, no classification shall be made, and no minimum wage rate shall be fixed, solely on a regional basis, but the industry committee and the Administrator shall consider among other relevant factors the following:

(x) competitive conditions as affected by transportation, living, and production costs;

(2) the wages established for work of like or comparable character by collective labor agreements negotiated between employers and employees by representatives of their own choosing; and

(3) the wages paid for work of like or comparable character by employers who voluntarily maintain minimum-wage standards in the industry.

No classification shall be made under this section on the basis of age or sex."

This paragraph seems potentially important and undoubtedly was regarded as a compromise which paved the way for enactment of the statute; but the only use thus far made of it has been by the Hosiery Committee, which is recommending

\footnotetext{
'Two, at least, of the recommendations hitherto made by industry committees include proposals to the effect that the employments in question shall be reviewed by committees for these industries, not more than one year after these recommendations are made effective.
} 
(unanimously) a minimum of $32 \frac{1}{2}$ cents for its seamless branch and 40 cents for its full-fashioned branch. It might be legal to establish occupational classifications, but this is a mooted point, and of course there is much less occasion for minimum rates of 40 cents or less for skilled than for unskilled workers. Moreover, the attempt to secure agreement on different minima within an industry, according to occupations, would add many difficulties to those involved in fixing a single minimum, applying mainly to workers of little skill. ${ }^{7}$

It will be observed that differentials according to sex and geographic regions, both of which were very commonly employed in the NRA codes, appear to be explicitly ruled out by this statute. Study of the clause "No classification shall be made ... solely on a regional basis..." (italics added), however, in its context, indicates that regional classifications might be valid if supported by strong evidence as to "relevant factors" like those cited in the law. This mandate might ultimately be held to sanction differentials according to population density (size of village, town, or city), which were also much used in the NRA, provided that the Administrator and the courts became convinced that living costs are generally lower in smaller than in larger places of work and residence. It is widely believed that a given money wage will produce a higher level of real wage in a smaller than in a larger city; and the somewhat smaller average size of cities in the South than in the North doubtless has accounted in part for the lower averages of money wages in the former region. The statistical data at present available, however, on variations in living costs suggest that differences within northern and southern regions are greater than differences between regions.

Subsections (d) and (e) of Section 8 specify the procedure of the Administrator after an industry committee has made its recommendation, and give some hints as to the lifetime of any committee, which hints are supplemented in the Administrator's regulations. These subsections read as follows:

"(d) The industry committee shall file with the Administrator a report containing its recommendations with respect to the matters referred to it. Upon the filing of such report, the Administrator, after due notice to interested persons, and giving them an opportunity to be heard, shall by order approve and carry into effect the recommendations contained in such report, if he finds that the recommendations are made in accordance with law, are supported by the evidence adduced at the hearing, and, taking into consideration the same factors as are required to be considered by the industry committee, will carry out the purposes of this section; otherwise he shall disapprove such recommendations. If the Administrator disapproves such recommendations, he shall again refer the matter to such committee, or to another industry committee for such industry (which he may appoint for such purpose), for further consideration and recommendations.

"(e) No order issued under this section with respect to any industry prior to the expiration of seven years from the effective date of section 6 shall remain in effect after such expiration, and no order shall be issued under this section with respect to any industry

${ }^{7}$ The recommendation of the Apparel Committee provides for a rather extensive subdivision of the industry with minima ranging from $32 \frac{1 / 2}{2}$ to 40 cents an hour. There are seven separate divisions under Women's Apparel, five under Men's Wear; and twelve under Accessories and Special Products. (1939)

2 WAGE \& HOUR REP. 297. 
on or after such expiration unless the industry committee by a preponderance of the evidence before it recommends, and the Administrator, by a preponderance of the evidence adduced at the hearing finds, that the continued effectiveness or the issuance of the order, as the case may be, is necessary in order to prevent substantial curtailment of employment in the industry."

It is quite clear, from subsection (d), that, if the Administrator disapproves of a committee's recommendations, he may dissolve that committee and appoint another one to study the industry and to make its recommendations. Conceivably this process might lead to several hirings and firings of committeemen for a single industry before a recommendation was adopted; in any case it is also clear that it is always the industry committee which proposes a minimum wage rate (within limits of the blanket rates for the period), whereas the Administrator disposes, subject to court review as mentioned below.

The final one of the Administrator's regulations relating to industry committees further interprets the law's provisions regarding the committee's lifetime as follows:

"Section 5Ir.22-End of committee's function. When a committee has submitted a report, as provided in section 5II.Ig hereof, it shall cease to perform any further functions until reconvened by the Administrator; provided, however, that the Administrator may dissolve the committee after it has submitted its report."

It seems probable that the Administrator will not dissolve a committee (in case he accepts its recommendation) until his own public hearings are concluded, because in this hearing it is the committee's, as well as the Administrator's, recommendation which is put forward for comment and criticism from any quarter. Since each committee contains anywhere from $\mathrm{I}_{5}$ to $4^{8}$ persons, and a considerable number of industries may have to be provided with committees, it is easily seen that dissolution of each committee after its report is made (or after the Administrator's hearing) reduces the opportunities for embarrassment of full-time members of the government by independent activities among all these committeemen of semi-official status. Clearly these industry committees play no part in enforcement of the law, as did the Code Authorities under the NRA.

Apparently Section 8, subsection (e), read in the light of Section 6, subsection (a), contemplates that the flexibility of minimum wage rates should not necessarily be in one direction only, but that at any time while the Act is in force the Administrator may appoint an industry committee, or call on any one which has already been appointed and not dissolved, for study and recommendation; and, if the preponderance of evidence sustains such recommendations, the existing minimum rate may be lowered, though not below 30 cents per hour.

Subsection (e) may well be modified somewhat, before October I945. As it stands, it is far from clear as to when the industry committee recommendations must be made in order to continue in force wage orders made before these seven years have expired, or to prevent the automatic application of the law's blanket 40-cent minimum, in 1945 , in any industry or industries. During I940-45 the Administrator 
must take the initiative, and sustain the burden of proof, to raise the effective minimum from 30 toward, or up to, 40 cents. Thereafter, as the law now stands, the position will be reversed, and he must take the initiative and sustain the burden of proof in order to lower the effective minimum to or toward 30 cents.

Although it is always the industry committee which proposes a wage order, the Administrator evidently has large indirect powers of initiative through his freedom of choice of committee men and his express power to reject the recommendations of any committee and to discharge that committee and appoint a new one for the same industry. These arrangements, however, are thought to satisfy constitutional requirements of due process and to avoid unconstitutional delegation of legislative powers to the Administrator. In case the Administrator dissolves any committee which has not made a recommendation, or rejects any committee's recommendations, presumably he would issue an explanation giving the particulars of his objection to the committee's procedure or recommendations or both.

Much informal contact is normal between the Administrator's staff and the personnel of the committees. If a committee at its organization meeting might wish to recommend at once a national minimum rate of 40 cents an hour for its industry, the Administrator's representatives would undoubtedly advise against such a move and would likely point out that such action by the committee would not fulfill the requirements of due process, in that it is not based on a hearing at which sufficient opportunity for submitting evidence is extended to all parties interested.

This mention of due process leads to some further consideration of the committee's procedure in gathering evidence, and of the provisions of Section to of the Act, providing for court review of the Administrator's orders. The latter point may be disposed of briefly, since no order has yet been issued and hence no possibility has arisen of court review. Section Io provides in part that:

"Any person aggrieved by an order of the Administrator issued under section 8 may obtain a review of such order in the circuit court of appeals of the United States for any circuit wherein such person resides or has his principal place of business, or in the United States Court of Appeals for the District of Columbia, by filing in such court, within sixty days after the entry of such order, a written petition praying that the order of the Administrator be modified or set aside in whole or in part.... The review by the court shall be limited to questions of law, and findings of fact by the Administrator when supported by substantial evidence shall be conclusive. No objection to the order of the Administrator shall be considered by the court unless such objection shall have been urged before the Administrator or unless there were reasonable grounds for failure so to do. ...."

No mention is explicitly made in the above section of the industry committee concerned; but in case any such order is reviewed, the court would doubtless give attention to the record of evidence collected by the committee, as well as its recommendation, in determining whether the Administrator's findings of fact were actually supported by substantial evidence. The industry committee's collection of evidence as the basis for its recommendation, which is thus a key point in the due process prescribed by this law, deserves some further comment here. These comments must 
be couched in general terms, since most particulars of the investigations thus far conducted have not yet been made public. The information brought to the attention of the committee is of two principal sorts: (I) that which is submitted to it by the Administrator's staff, and (2) that which comes from interested persons.

Within the first of these categories special importance attaches to wage statistics collected by the United States Bureau of Labor Statistics, some of these data being collected with particular reference to the needs of the Wage and Hour Administrator. Tabulations of the latest such materials available, as well as the most nearly relevant census data, are likely to be made available to members of each committee at its organization meeting; and the Administrator's staff secures more data and makes further analyses as the committee's work proceeds. One comprehensive exhibit of the data thus provided by the Administrator's staff for the Textile Committee, through the cooperation of the U.S. Bureau of Labor Statistics, is the survey of hours and earnings in cotton manufacturing. ${ }^{8}$ Such wage data are samples, not complete censuses; but they give reliable indications, e.g., as to how many workers in the industry, of each sex, were (in the period of the survey) earning less than 25 cents, how many less than $27^{1 / 2}$ cents, and so on; also in what states and in what sizes of plants these lowest-paid workers were employed.

The above-cited wage survey in cotton-goods manufacturing, for example, showed that in August $1938,8.3$ per cent of all workers in a large sample (3r9,000 employees) were earning below 25 cents an hour, and that most of these were in the South. Many of these people, presumably, were raised to 25 cents when the Fair Labor Standards Act took effect, October 24, I938. The same survey showed that, in August 1938, 34.7 per cent of all the workers covered were earning below $32 \frac{1}{2}$ cents; here is one measure of the meaning of this committee's proposal of a $321 / 2$-cent minimum, to be set as soon as possible. Naturally these low earnings were heavily concentrated within "unskilled" occupations, and in the South-a little over 6 per cent of all workers in the Northern sample earned below $32^{1 / 2}$ cents, contrasted with 44.2 per cent of those in the Southern sample. ${ }^{9}$ These scraps of data illustrate the materials at hand, and convey an idea of the magnitude of the task. ${ }^{10}$

With regard to evidence submitted to an industry committee by interested persons, reference has already been made to the committee's powers of subpoena; and orders may also be issued for the taking of testimony by deposition. Up to the present time, however, these powers of subpoena and deposition have not been exercised; whereas considerable use has been made of public and semi-public hearings in which interested persons may voluntarily appear and submit such evidence and arguments as they choose. Stenographic records are made of proceedings in committee meetings

\footnotetext{
${ }^{8}$ Hinrichs, Wages in Cotton-goods Manufacturing. U. S. Bureau of Labor Statistics, Bulletin No. No. 663,1938 .

${ }^{9} I d$. at $8 \mathrm{r}-84$.

${ }^{10}$ It should also be remarked that the Southern cotton manufacturers complied with the 30-cent minimum for inside workers of the NRA in 1933 - and with a $221 / 2$ cents minimum for outside laborand that the blanket 30-cent minimum will apply to all its workers from October 1939, except as modified upward through acceptance of a recommendation by the industry committee and the Administrator-and except for a small number of learners and handicapped workers.
} 
of all sorts, at least so far as the Administrator's funds permit, and mimeographed copies are circulated among committee and staff members.

The "interested persons" who thus appear before the committee have consisted almost exclusively of officials of trade associations and trade unions directly concerned. The sections of employers and workers of the industry who are organized but little or not at all (many of these in small and/or remote establishments) are likely to be represented only very indirectly; and, of course, the same may be said of the general public and consumer interests. The implications of these representations will be discussed a bit in my concluding section.

The last matter to be noticed under our heading, "Procedures and Problems," is the time consumed in reaching committee recommendations. Various critics consider that these processes have been unduly deliberate and that some industries should have had minimum wages set above 25 cents an hour within a few months after the law took effect. The processes of collecting information and digesting it and deliberating over it, which are required for full compliance with the law and with the Constitution, at best consume more time than is agreeable to some of these critics; and some members of a committee might conceivably exercise dilatory tactics, even up to the point where the Administrator would discharge the committee for failure to make reasonable progress. It seems probable, however, that not much of the time which has elapsed since appointment of industry committees was begun is attributable to slowness of work within the committees. The rather narrow limits within which the minimum wage rates may be modified by the Committees and the Administrator, and the tendency to draw the personnel of the committees from the most highly organized sections of their industries, make it probable that a committee will not require many meetings or very long deliberations to reach a recommendation. A much more important limiting factor is the capacity of the Administrator's staff to deal with the innumerable other urgent problems which are presented to them, and at the same time to see that each committee's work is carried on in the light of the most adequate information that can be made available. This limitation, of course, is in large part dependent on funds allotted for the administration of the Act.

\section{Some Inferences with Reference to Constitution, Work, and Problems of THE Industry Committees}

The matters discussed above may now be reviewed in another fashion through an attempt to state succinctly the significant features of the industry committees. For this purpose I shall concentrate on two aspects, or sets of issues, namely: (I) What sort of advisory committee structure is likely, economically, to give due process of law, and to command adequate political support in the fixation of minimum wage rates, industry by industry? (2) How do and how should the industry committees appraise the extent, causes, and treatment of low wages in their trades? Should the low-wage sections be regarded as "chiselers"?

(I) Due Process and Political Support. I gather that the industry committee pro- 
visions of the Act were of some importance in securing political backing for the latter, for at least two reasons: (a) the committee scheme is part of a prescribed procedure which was calculated to avoid the constitutional rocks on which the NRA foundered; and (b) liberal-to-conservative people regard the industry committees as checks and balances tending to modulate any inclination which the Administrator might have, or develop, toward raising minimum wage rates too far and too fast. With the changed outlook of the Supreme Court the former consideration, I suppose, has become less weighty (though legally-minded friends of the law are still concerned to minimize constitutional grounds for objection to its provisions and administration); and the irritation which has developed in some labor quarters at this law's delay is no doubt directed in part at the time and expense required to get recommendations through the industry committees.

From other points of view, too, the industry committees produced by this law are somewhat vulnerable to criticism, at least as contrasted with smaller and fuller-time advisory committees (more or less as used by the NRA), the latter type of board advising with reference to larger factors and sections than do the industry committees of the present Act. The immense complexity of the national wage, hours, living-cost, and price structures, and the information needed for this new venture in national minimum wage regulation, are not fully comprehended by anyone; and it is rather optimistic to hope that the majorities of all or most of the committees will become aware of the "right questions to ask," or pay sufficient attention to the information which the Administrator's staff and the interested parties make available to them. I presume no one can say how many more industry committees will be appointed, even within the next year or so; but probably there remain scores of trades of interstate significance, each with sufficient industrial consciousness and sufficient workers paid less than 40 cents an hour, to require appointment of such a committee. Considerations of traveling expense and of the assistance required from the Administrator's staff for each committee and subcommittee make it impossible for more than a small fraction of the committeemen to be able to improve appreciably their original guesses as to which minimum rate or rates (taking due account of potential classifications in each industry) will produce just less than "substantial unemployment" in each industry.

The Administrator, to be sure, is able in some measure to keep down the number of active committeemen, under the existing law, by means of various devices. One, already in use, is delegation of important problems to subcommittees. Another is appointment of the same person to more than one committee. Something more might be done toward persuading employers in the industries yet to be organized, to be content with smaller representations than have hitherto been appointed, in which case the labor and public delegations could be made correspondingly smaller without much objection, it is believed, from any quarter. Conceivably some scheme might be devised for amending the law to permit unequal numbers of persons (with equal unit voting powers) among the public, employee, and employer groups in each 
industry committee; but in this case one difficulty would lie in making satisfactory provision for a quorum.

Even if the committees are smaller in the future, however, the number of industries requiring committees seems inevitably to make the number of committeemen large, in relation to the services which the Administrator's staff can provide; and this circumstance, together with the rather short lifetime of each committee, seems a bit unfavorable to the sound principle thus enunciated by the Administrator: "The result should be wage recommendations predicated on facts and not arrived at either by coercion or by swapping concessions." 11

In short, the present advisory system helped to secure early acceptance and support of the law by organized employers and labor. But if, by reason of the characteristics sketched above, it comes to be thought to operate inefficiently, there might develop a serious reaction against it, as pressure groups in the industries became dissatisfied. And if organized employers or labor, or both, to a material extent should become uncooperative, not only would the enforcement of the existing minima become much more difficult, but also the upgrading of minima from 30 toward 40 cents would be retarded, and a crisis might develop as the universal 40-cent minimum of 1945 drew near.

(2) Unorganized Employers and Workers: "Chiselers" or Forgotten Men? We may reasonably assume that all or nearly all members of the industry committees consciously try to act in the general public interest, and that in not a few instances they do voluntarily sacrifice the interests of themselves and of their ordinary associates to this end; though of course lower standards of appointment than have thus far prevailed might appear in the future. A much larger problem, I think, than the intentions of the committeemen lies in their ability to assess correctly the interests and problems of all groups affected by wage orders in their respective industries. However large the committee and however small its industry, not all sections and groups in the industry can be directly represented by these committeemen. The law, it will be recalled, quite properly provides for consideration of geographical sections in the appointment of committee members; and necessarily the organized employers and workers can be most effectively represented. "Effectively represented" is used here with a double significance-in the sense of knowledge of the needs and capacities of constituents, and in the sense of the enormously greater political power of a representative who has a strong pressure group behind him, as compared with a representative who tries to speak in behalf of the needs of an equal number of other persons, who, however, cannot be depended upon to vote as a bloc. From this latter standpoint it may be anticipated that, in the long run, the Administrator will tend to attach less weight to the views of the public committeemen than to those representing workers and employers.

It seems probable that the employers and workers in the lowest-wage plants tend to be less strongly organized than the higher-wage groups; and that the workers in the former category are more largely outside trade unions, and in shops of small and

11 (1939) 6 LaB. INF. Bull. No. 4, p. 3. 
remote employers who have little influence or participation in trade associations. Many of the lowest wages are in rural to small city locations; and this density-ofpopulation factor interacts with other factors. For instance, wages tend to be low in areas within which the industry is under especially severe financial pressure and is tending to disappear, as well as those in areas within which the industry is growing, partly on the basis of using workers accustomed to still lower incomes, and where cost of living is perhaps somewhat lower than in the more strongly organized centers. Building costs, for example, may be higher where building labor is strongly organized. It is impossible to appraise accurately the probable impact of any contemplated wage regulation on a complex of this sort, and each industry committeeman naturally is most clearly aware of a proposed wage order's bearing on the part of the industry with which he is personally associated. The representatives of organized employers and workers both are likely to regard the low-wage payer and also the low-wage receiver as "chiselers" who secure private advantage by undercutting the rates of the organizations within their respective fields.

The employers in each section and classification of the industry naturally hope that the new wage and hour regulations will bear more heavily on competitors, particularly those in other regions, than on themselves. The NRA labor provisions were obviously supported by many employers and others in this spirit. And among considerations which influence the trade union committeemen are the getting rid of their employers' arguments based on the low wages of (perhaps distant) competitors, and letting government take responsibility for any unemployment of labor and capital which may follow from raising the minimum wage.

Since it is utopian to imagine the appointment of individuals who could much more adequately and directly interpret the positions of the unorganized workers and employers than do the present committeemen, a rather special responsibility lies upon the public members to try to see that the interests of all sectors of the industry, as well as of consumers, are given full consideration. Some of the public members, however, doubtless have parochial views, some are rather employer-minded, others may have opposite inclinations. And, in between the extremes, there are innumerable variations based on the natural limitations of human knowledge and attitudes. The southern public members of the Textile Committee voted with southern employers against a $32 \frac{1}{2}$-cent recommendation, and the scraps of data given above ${ }^{12}$ show that their position had at least one rational "leg to stand on."

The law's warning against causing "substantial unemployment," to be sure, implies that it shall not be necessary to demonstrate beyond reasonable doubt that no fresh unemployment will be produced by any minimum wage order; and it is widely agreed that this is a sound and progressive position. Yet new unemployment which is a negligible percentage of all workers in an industry may be very substantial with reference to low-wage localities. This consideration was doubtless in the minds of the persons who drafted subsection (c) of Section 8, which provides that, if any industry committee does recommend classified rates, it

${ }^{12}$ Page 36r, stipra. 
“... shall recommend for each classification in the industry the highest minimum wage rate which the committee determines will not substantially curtail employment in stich classification." (Italics added).

Might any of the difficulties surveyed above be mitigated, by modifications of the law or administration with reference to the industry committees? It is always much easier to recognize elements which are not quite satisfactory than to prescribe dependable means of improvement; moreover, my own information is much too limited for detailed constructive suggestions. It seems to me it has been wise to make haste rather slowly up to this time, but that some acceleration of the processes may be hoped for in the near future-the administration must discharge its duty to low-wage earners as promptly as possible and prompt action will moreover tend to reduce the mass of uncertainties which are retarding business activity. The public memberships in the industry committees seem to give more effective neutral advice and influence than has been provided as yet in most of our other governmental agencies. My remarks above on the lack of thoroughness which must characterize much of the work of the industry committees under present conditions must not be interpreted as doubt that these committees are valuable adjuncts to the Wage and Hour Administration. Each industry is the source of livelihood of tens to hundreds of thousands of families, its problems are extremely complex, and these are deserving of careful study by its own committee.

My impression is, however, that some formal intermediate organization might be helpful, between the Administration and the industry committees. It is true that the Administrator's staff in an important sense provides two-way communication between the Administrator himself and the industry committees; but I suggest there might be considerable benefit from an advisory committee of larger scope, or perhaps more than one. Such a committee, or committees, should be tripartite (containing representatives of the public, of employers, and of employees), and would doubtless be recruited from industry committee members, with regard especially to their apparent talents and attitudes, and only secondarily with regard to geographic and industrial distribution. These individuals should retain "amateur standing" by per diem pay rather than salary, and, by giving longer and more intensive service, they should learn much more about interrelations in the whole wage and hour structure than can most of the present committeemen. No doubt any executive must always rely heavily on informal advice from some sort of "kitchen cabinet" (i.e., those people whose advice, at the moment, he considers best), and any formal super-committee might reasonably be considered an encumbrance. Yet the obvious merits of the recognition and responsibility of a formal advisory committee might well outweigh its less desirable characteristics.

Although each industry committee is directly concerned only with wage variations within its industry, in the long run the Administrator must deal through the committees with variations among all industries and sections; and a few of the interrelations among these differences may be briefly suggested in closing. The intention of 
the Act apparently is to enforce as near a 40-cent hourly minimum as soon as possible, in every industry in which not more than a moderate amount of unemployment will be thereby produced. This minimum rate is to be set with little, if any, reference to the relative steadiness of work in the industries and establishments affected. The hours and overtime provisions of the law do operate, to some extent, in favor of decasualization of labor; and among proposed amendments to the Act is at least one, referring to hours and overtime, which would encourage "constant wage" arrangements. It is to be hoped that the minimum-wage-setting processes will not exert pressure against decasualizing forces.

Among industries, there are already many differences in minimum earnings beyond those reasonably explicable by variations in qualities of the respective unskilled labor supplies and in the comparative repugnance of the tasks. In effect, the high-wage industries appear thus to carry out a sort of de facto profit sharing-in part, perhaps, by reason of sluggish flows of capital and labor into them. The Fair Labor Standards Act adapts itself to such variations (among the low-wage industries), and a main purpose of the industry-committee apparatus is to provide for variability of minimum wage rates in accordance with current abilities of industries to pay. Up to the present time the committees and the Administrator have been obliged to estimate effects of various hypothetical minima, between 25 and 40 cents, upon employment. After orders begin to be issued, and as statistical data and other evidences continue to be accumulated, a broader base of experience will be had for future actions.

Within many industries, as noted above, there are also marked wage differences, in the causation of which such factors as "migration of industry," quality and price of product, and labor organization may be discerned. Probably in the more highlyorganized sections there remain relatively few workers who are exploited in the sense of being paid less than the local going rates for similar services, and of course the hourly earnings of organized labor tend to be higher than of unorganized. Under some conditions the prices of the former's products are thereby raised; and both employers and workers in these unionized sections are directly benefitted in the degree that the government enforces increases of wage rates in the less organized sections. Contrariwise, the employers whose labor is not yet effectively organized tend to expand operations by means of lower prices based upon low, sometimes shockingly low, wages, so far as a labor supply is thus available, presumably because its alternative opportunities are still less favorable. If the latter sections are allowed to expand, their wages tend to rise with increasing demand and with increasing labor organization; and the former sections are faced with many distressing problems of deflation-which, however, also supply stimuli toward utilization of increasingly efficient methods of production. In these considerations we find further confirmation of the wisdom of the "without substantially curtailing employment" language of the Act, and of the tendency of the committees to recommend single national minima, intermediate between those prevailing in the highest- and lowest-wage sections of their respective industries. 